\title{
The Impact of Management Information Systems of Human Resources on the Training Needs in Al-Balqa Applied University
}

\author{
Mohammed A. Abu Rumman \\ Department of Business Administration \\ Al Balqa Applied University, Salt-Jordan \\ Tel: 692-777-774-819 E-mail: abusharare_77@hotmail.com
}

Received: April 8, 2013 Accepted: April 23, 2013 Published: June 25, 2013

doi:10.5296/bms.v4i1.3501

URL: http://dx.doi.org/10.5296/bms.v4i1.3501

\begin{abstract}
The purpose of this study is to identify the impact of management information systems of human resources on the training needs in Al-Balqa Applied University and to get out practical recommendations to solve them. It also aims to show the possibility of determining the goals of the training programs, and to evaluate and follow-up training programs offered by the Human Resource Management at the university.

The Findings indicate that there is statistically significant relationship between management information systems of human resources and identifying training needs and setting of training programs goals in the Al Balqa Applied University. The findings also indicate that there is a statistically significant relationship between management information systems of human resources and evaluation and follow up the effectiveness of training programs at Al Balqa Applied University.

The study recommended that there is need to identify of training needs at the university level in the long term, when designing management information systems of human resources. The study recommends that there is need to take into account identifying the individual needs of the management information system of human resources and the management information system of human resources should help in analyzing and treating goals to reach to the quality of the training programs.
\end{abstract}

Keywords: Management, Information systems, Human resources, Training needs 


\section{Introduction}

Business enterprises have many resources that used to improve performance levels and to achieve their goals. The most important and effective resource is the human resources, which is considered first and fundamental wealth to the institution and a key factor for the performance, which allow the institution to stay, continue and grow within an un stable environment and markets and more complex and diverse products, in addition to the difficulty of customer satisfaction and achieve the highest level of productivity and efficiency. This policy (performance improvement) consider as a general policy of the institution, where there is conviction to activate the human resources of the senior leadership to executive levels in all areas. The human resource represents all employees in the organization and at all levels, their qualifications and their roles.

Organization cannot be created or organized without human resource, so administrative schools in All Ages to the present time focused on this resource. Therefore, the administrative schools promote, develop their abilities and to monitor their underlying knowledge. The administrative schools have worked to create internal and external environment in order to do the actions and activities assigned to him efficiency. The human resource organize, control and exploitation of various resources and material and technical, financial, technological resources owned by the institution, as human resource works on the distribution of roles and defines the powers, delegated and supervised activities and tasks. Without the human resource goals cannot be achieved. Human resources have become one of the main effective competitive factors in the institution which gave it a strategic dimension in its management, making the human resources turns from function framework to its strategic role because the traditional role of human resource is no longer enough to achieve competitive discrimination in the organization.

The administration asks according to strategic perspective to drives human resources activities to help the organization to achieve its objectives, hence, the strategic management process of human resources includes assessment of the skills required to run the institution and imposes control in the quality of human resources and employment inherent knowledge, because the institution performance relies on it.

The economic organizations face many challenges as a result of the fast and deep development of the business world in several areas, whether it is economic, social, or political reflected more or less on economic organizations and make them in permanent conflict with perimeter characterized by competition, not necessarily to achieve progress and prosperity but often to preserve its survival.

The heart of this evolution in the field of information technology and what will be of change in the concepts and the emergence of new resources. It becomes necessary for the organization, to control and exploit it best to achieve the advancement and especially the information resource, which is a strategic resource in the process of performing organization. It also requires effective and efficient in dealing with human resource that can only be achieved to the availability of integration and harmony between all levels of the organization and between all functional systems. 
Organization consists of several functional systems and they work in harmony and by ensuring the effectiveness of all operations and activities and control of the vast amount of information resulting from it. It is providing managers with accurate information in time and properly to take appropriate decisions in order to achieve the objectives underlined by the administration.

\section{Problem of the Study}

Human resources have become one of the main effective competitive factors in the institution which gave it a strategic dimension in its management, making the human resources turns from function framework to its strategic role because the traditional role of human resource is no longer enough to achieve competitive discrimination in the organization. Therefore there is need to investigate the impact of management information systems of human resources on the training needs in Al-Balqa Applied University.

\section{Objectives of the Study}

1) To identify the training needs in the Balqa Applied University.

2) To show the possibility of determining the goals of the training programs offered by the Human Resource Management at the university.

3) To show the extent the possibility of the realization and implementation of these training programs.

4) To evaluate and follow-up training programs offered by the university for its employees.

\section{The Importance of the Study}

The importance of the present lies in studying of management information systems of human resources, identifying of training needs, in addition to set the training goals, and evaluation and follow-up the activities of the training programs in the BAU.

\section{Literature Review}

Sharif (2006), conduct a study to identify the risks facing electronic accounting information systems in the banks and to identify the most important reasons that lead to the occurrence of such risks and actions that prevent the occurrence of such risks. The findings indicate that good administration can reduce or limit the occurrence of risks facing the accounting information systems at banks. It also found that the application of information systems security reduce the potential risk of accounting information systems.

Al Mahasneh (2005) conduct a study to identify the impact of the efficiency of information systems in the effectiveness of the decision-making process. The study explained the role of organization's managers in providing a basic rule of inclusiveness and specialist information systems to strengthen their role in making suitable decisions. The finding indicates the impact of the information systems on the physical, financial, technical, human resources and administrative in identifying the problem and development of alternatives and comparison between alternatives. The study recommended that the supreme department should provide support for users by encouraging them to use the system and to identify their needs and the need for their participation in the development of computerized information system. 
Judeh (2004) investigated the impact of accounting information systems used in the Income Tax department on increasing the effectiveness of the income tax department in Jordan through the impact of the development of accounting information systems used in the department, the interest of the income tax by providing skilled manpower and material resources to the Directorate of Information. The study focused on the development of computers and software used in accounting information systems in the income tax department, as well as the role of departments and public and private institutions in the provision of accounting information which is useful in quantity and quality to the income tax department. The findings show that increasing of the effectiveness of the Income Tax Department are affected by all the independent variables such as the contribution of computer and software used in accounting and information systems as well as the development of accounting information systems in the Income Tax Department. The study recommended the need for a link Directorate of Information with the head of administrative hierarchy of the income tax department to implement the plans of collecting information to suit the importance of accounting information to the Department.

Siam (2004) assess the effectiveness of computerized accounting information systems in the Jordanian commercial banks in the light of technological development, through a set of criteria that reflect the effectiveness of the performance of these systems and represented by quality, flexibility, simplicity and reliability. The study focused on the role of accounting information systems as the backbone of the information systems in banks. The finding showed that the computerized accounting information systems in the Jordanian commercial banks are characterized by the availability of four characteristics, namely, (quality, flexibility, simplicity, and reliability) combined, according to the following descending order: 1-quality 2- Reliability 3- Flexibility 4 -simplicity. The study recommended the need to take advantage of the means of modern information technology in the development of computerized accounting information systems Jordanian commercial banks.

Jaafar (2003) conducted a study to identify the theoretical and applied foundations for the accounting system which, appropriate to the administrative system and represented mainly in making the standard, comprehensive and integrated accounting system constituents be an effective tool for planning, control, and evaluate the financial performance. The study focused on selecting the appropriate accounting policies for the application of the administrative system. As well as focused on the component and the basic elements of accounting system which appropriate for the application of the administrative system by its goals successfully. The findings indicate that the companies applied accounting system consolidated verdict No. 287 of 1978. In addition there are many of the gaps that characterize the system theoretically but it in practice side there is no cost accounting division and therefore, the absence of the application of the scientific basis for setting performance indicators and preparing planning budgets as scientific tools for planning, control and application of the administrative system by its goals. The study recommended the need to provide a appropriate accounting system that produces appropriate information for the purposes of planning, control, performance evaluation and decision-making which allows rationalization of expenditure and force costs and reduce waste and spoiled in order to increase profits. 
Khatab (2002) examined the factors affecting the efficiency and effectiveness of accounting information systems in the Jordanian commercial banks. The study focused on the extent of the impact of models of administrative decisions on the efficiency and effectiveness of accounting information systems used in the Jordanian commercial banks. The study also focused on the impact of computer hardware and software on the efficiency and effectiveness of accounting information systems used in the Jordanian commercial banks. Findings indicate that the highest impact of environmental factors on the efficiency and effectiveness of accounting information systems used in the Jordanian commercial banks is regarding the regulations and standard accounting and audit rules used in the bank. The study showed that behavioral factors of the users of information effect on the efficiency and effectiveness of accounting information systems used in the Jordanian commercial banks. Also finding indicates that the hardware and software used in the bank has significant impact on the efficiency and effectiveness of accounting information systems used in these banks.

Ramadan (1999) in his study showed a relationship between the company environment and the accounting information system used in Jordanian public shareholding industrial companies and method of making the administrative decision in the organization depends on the nature of the accounting system used in these companies. Finding also indicates that there is no relationship between organizational factors and accounting information systems, because the companies are not aware of the extent of the contribution of these factors represented by (decentralization, integration and bureaucracy) to make a significant impact on the characteristics of accounting information systems.

Salah (1995) investigated the development of the accounting information system, and determined its causes and identify its impact on routing in the modern project. The study also focused on the significant role that the information played in the modern organization, and the important role played by accounting information to facilitate economic decision-making processes. The study was based on the methodology of historical extrapolation through two stages that is traditional and modern accounting.

Abdel Razaaq (1993) conducted a study to identify the extent of the use of accounting information in the administrative decisions relating to the planning, control job and the application to all the Jordanian Industrial companies listed in the Amman Financial Market. Finding indicates that senior administration (decision makers) in companies of the Jordanian Industrial use accounting information inferred from the reports and financial statements in making administrative decisions.

Jamoos (1991) conduct a study to review of accounting systems that rely on the use of computers. This study focused on the role of accounting as a system of information and it explained accounting information systems that rely on the use of computer related to the quality of control and review these systems which need to evaluate the information systems used by economic unity. The findings of the study indicate that to clarify the role of the auditor to detect weaknesses in these systems. These systems rely on modern automated methods in the application of accounting processes and the study showed a lot of points that can only detect by expert in programs and applications. The study recommended following up the process of automation of the data and the need for a periodic review of operating systems and the importance of ensuring the use of automated systems elaborately. 


\section{Macrothink}

Nadari (1990) conducted a study to look at the efficiency of information systems and their impact on the decision effectiveness in the Jordanian commercial banks. The finding shows a positive relationship between the effectiveness of decision-making and information systems in Jordanian banks.

\section{Methodology}

This study considered as pilot, analytical study and it pursues collection and analysis of data to reach the results. The purpose of this study is to identify the impact of management information systems of human resources on the training needs in Al-Balqa Applied. Hundred questionnaires were distributed, (90) questionnaire were returned and 21 questionnaires were excluded. Therefore, the study relied on (69) questionnaires and representing the community and sample of the study.

\subsection{Hypotheses of the Study}

Based on the study aim and objectives, the following hypotheses can be formulated:

H1: There is statistically significant relationship between management information systems of human resources and identifying training needs in the BAU.

$\mathrm{H} 2$ : There is statistically significant relationship between management information systems of human resources and identifying the goals of training programs in the BAU.

H3: There is statistically significant relationship between management information systems of human resources and implementation of human resources training at the BAU.

H4: There is statistically significant relationship between management information systems of human resources and evaluation and follow up the effectiveness of training at Balqa Applied University.

\subsection{Stability of the Tool}

Cronbach's $\alpha$ (alpha) as a coefficient of reliability was used to measure the internal consistency for all variables. Table (1) shows the following:

1) The value of alpha for identifying training needs is 0.67

2) The value of alpha for setting goals of training programs is 0.88 .

3) The value of alpha for implementation of training programs is 0.84

4) The value of alpha for evaluating and follow up the effectiveness of training programs is 0.76

5) The value of alpha for all the statements is 0.87

All of these values are higher than 0.60 , which indicate the stability in the instrument of the study. 
Table 1. Cronbach's Alpha

\begin{tabular}{|c|c|c|c|c|c|}
\hline Statement & & $\begin{array}{l}\text { Alpha } \\
\text { Cronbach }\end{array}$ & Statement & & $\begin{array}{l}\text { Alpha } \\
\text { Cronbach }\end{array}$ \\
\hline $\begin{array}{l}\text { Identifying } \\
\text { training needs }\end{array}$ & -------- & \multirow[t]{3}{*}{0.67} & 16 & 0.49 & \\
\hline 1 & 0.73 & & 17 & 0.71 & \\
\hline 2 & 0.92 & & 18 & 0.73 & \\
\hline 3 & 0.76 & & 19 & 0.71 & \\
\hline 4 & 0.78 & & 20 & 0.57 & \\
\hline 5 & 0.85 & & 21 & 0.65 & \\
\hline \multirow[t]{2}{*}{6} & 0.61 & & 22 & 0.71 & \\
\hline & & & $\begin{array}{l}\text { Assess and } \\
\text { monitor the } \\
\text { effectiveness } \\
\text { of training }\end{array}$ & -------- & 0.76 \\
\hline $\begin{array}{l}\text { Setting goals of } \\
\text { training } \\
\text { programs }\end{array}$ & -------- & \multirow[t]{4}{*}{0.88} & & & \\
\hline 7 & 0.42 & & 23 & 0.56 & \\
\hline 8 & 0.68 & & 24 & 0.52 & \\
\hline 9 & 0.71 & & 25 & 0.51 & \\
\hline 10 & 0.72 & & 26 & 0.36 & \\
\hline 11 & 0.32 & & 27 & 0.63 & \\
\hline \multirow[t]{4}{*}{12} & 0.63 & & 28 & 0.78 & \\
\hline & & & 29 & 0.72 & \\
\hline & & & 30 & 0.63 & \\
\hline & & & 31 & 0.68 & \\
\hline $\begin{array}{l}\text { Implementation } \\
\text { of training } \\
\text { programs }\end{array}$ & -------- & 0.84 & 32 & 0.57 & \\
\hline 13 & 0.79 & & 33 & 0.61 & \\
\hline 14 & 0.54 & & 34 & 0.71 & \\
\hline 15 & 0.62 & & All statement & ------ & 0.87 \\
\hline
\end{tabular}


6.3 Description of Demographics and Functional factors of the Respondents:

Table 2. below shows that:

- First: Gender: Gender: $65.2 \%$ of the samples are male, and the rest are female.

- Age: $46.8 \%$ of the samples' age range between $26-29$ years, and $21.7 \%$ of the samples' age more than 34 years. $18.8 \%$ of the samples' age range between $30-34$ years, and $11.7 \%$ of the samples range between $20-25$ years old.

- Education Level: $34.8 \%$ of the samples are bachelor's degree holders. $21.7 \%$ are Master degree holders. $13 \%$ are $\mathrm{PhD}$ degree holders and $11.7 \%$ of the samples are high school and less.

- Experience: $31.9 \%$ of the sample whose experience range between 5-7 years, $26.1 \%$ of respondents whose experience range between $2-4$ years, $21.7 \%$ of respondents whose experience one year or less and $20.3 \%$ of the sample whose experience more than 7 years.

- Salary: $49.3 \%$ of the samples salary range of $200-350,20.3 \%$ of the samples salary range of $351-500.17 .4 \%$ of the samples salary more than 650 , and $13 \%$ of the samples salary range between 501-650.

Table 2. Frequencies and percentages for personal variables of respondents:

\begin{tabular}{|l|l|l|l|}
\hline Variables & & Frequencies & Percentages \\
\hline Gender & Males & 45 & 65.2 \\
\hline Age & Females & 24 & 34.8 \\
\hline & $25-20$ & 8 & 11.7 \\
\hline & $29-26$ & 33 & 47.8 \\
\hline Qualification & $34-30$ & 13 & 18.8 \\
\hline & More than 34 & 15 & 21.7 \\
\hline & High School & 8 & 11.7 \\
\hline & Diploma & 13 & 18.8 \\
\hline & Bachelor & 24 & 34.8 \\
\hline & Masters & 15 & 21.7 \\
\hline
\end{tabular}




\begin{tabular}{|l|l|l|l|}
\hline & Phd & 9 & 13.0 \\
\hline Experience & Less than 1 years & 15 & 21.7 \\
\hline & $4-2$ & 18 & 26.1 \\
\hline & $7-5$ & 22 & 31.9 \\
\hline Salary & More than 7 years & 14 & 20.3 \\
\hline & $350-200$ & 34 & 49.3 \\
\hline & $500-351$ & 14 & 20.3 \\
\hline & $650-501$ & 9 & 13.0 \\
\hline & More than 650 & 12 & 17.4 \\
\hline
\end{tabular}

\subsection{Testing Hypotheses}

\subsubsection{First Hypothesis}

H1: There is statistically significant relationship between management information systems of human resources and identifying training needs in the BAU.

Table (3) below shows that all the statements got means grater than 3.00, except the statements No (2) and (5). The statement No. 1, which measures the extent to which the management information system of human resources on the identification of training needs at the unit level, got highest mean 4.12. The statement No. 4, got lowest mean 3.52 which measures how management information system is able to help in identifying the training needs that appropriate with the job description.

The statement No. 2 got 2.55 mean which is less than 3.00, which mean that management information system of human resources does not help to identify the training needs at the university level in the long term. The statement No. 5 got 2.96 mean which is less than 3.00, which mean that management information system human resources does not help to determine individual needs.

Overall means was of 3.45 and level of significance is less than 0.05 which indicate that the first hypothesis is accepted, and there is statistically significant relationship between management information systems of human resources and identifying training needs in the BAU. 


\section{I Macrothink}

Table 3. Mean, standard deviation, $\mathrm{t}$ value and level of significance regard identifying training needs.

\begin{tabular}{|c|c|c|c|c|c|}
\hline No. & Statement & Mean & $\begin{array}{l}\text { Standard } \\
\text { Deviation }\end{array}$ & t-Value & $\begin{array}{l}\text { Level of } \\
\text { Sig }\end{array}$ \\
\hline 1. & $\begin{array}{l}\text { Management information system of } \\
\text { human resources works on the } \\
\text { identification of training needs at the } \\
\text { unit level }\end{array}$ & 4.16 & 0.87 & 11.09 & 0.00 \\
\hline 2. & $\begin{array}{l}\text { Management information systems of } \\
\text { human resources help to identify the } \\
\text { training needs at the university level in } \\
\text { the long term. }\end{array}$ & 2.55 & 1.02 & $3.65-$ & 0.00 \\
\hline 3. & $\begin{array}{l}\text { Management information systems of } \\
\text { human resources help to identify the } \\
\text { training needs at the university level in } \\
\text { the short term. }\end{array}$ & 3.71 & 1.14 & 5.18 & 0.00 \\
\hline 4. & $\begin{array}{l}\text { Management information system is able } \\
\text { to help in identifying the training needs } \\
\text { that appropriate with the job } \\
\text { description. }\end{array}$ & 3.52 & 1.12 & 3.87 & 0.00 \\
\hline 5. & $\begin{array}{l}\text { Management information system human } \\
\text { resources help to determine individual } \\
\text { needs }\end{array}$ & 2.96 & 1.27 & 0.29 & 0.78 \\
\hline 6. & $\begin{array}{l}\text { Management Information } \\
\text { provides conditions for } \\
\text { resources training. }\end{array}$ & 3.78 & 1.14 & 5.72 & 0.00 \\
\hline & Total & 3.45 & 0.63 & 5.86 & 0.00 \\
\hline
\end{tabular}

\subsubsection{Second Hypothesis}

$\mathrm{H} 2$ : There is statistically significant relationship between management information systems of human resources and identifying the goals of training programs in the BAU.

Table (4) below shows that all the statements got means greater than 3.00, except the statements No (9) and (11). The statement No. 7, which measures the extent to which management information systems of human resources in clarify the objectives of the training programs through the training programs, got highest mean 4.04. The statement No. 10, got mean 3.96 in the second rank which measures how management information system of human resources helps in achieving the requirements of training staff. The statement No. 8, got lowest mean 3.55, but it statistically acceptable, which measures the extent to which the management information system of human resources in measurable goals through training 


\section{I Macrothink}

Business Management and Strategy

ISSN 2157-6068

2013, Vol. 4, No. 1

programs. The statement No. 9 got 2.75 mean less than 3.00, this shows that management information system of human resource helps to analyze and treat goals to reach to the quality of the training programs. The statement No. 11 got 2.93 mean less than 3.00 that is Equipment (Hardware) considered suitable and appropriate for the goals that have been set and pre-defined training programs at the corporate level.

Overall means was of 3.50 and level of significance is less than 0.05 which indicate that the second hypothesis is accepted, and there is statistically significant relationship between management information systems of human resources and identifying the goals of training programs in the BAU.

Table 4. Mean, standard deviation, $t$ value and level of significance regard setting goals of training programs:

\begin{tabular}{|c|c|c|c|c|c|}
\hline No. & Statement & Mean & $\begin{array}{c}\text { Standard } \\
\text { Deviation }\end{array}$ & t-Value & $\begin{array}{l}\text { Level of } \\
\text { Sig }\end{array}$ \\
\hline 1. & $\begin{array}{l}\text { management information systems of } \\
\text { human resources works in clarify the } \\
\text { objectives through the training } \\
\text { programs }\end{array}$ & 4.04 & 0.86 & 10.02 & 0.00 \\
\hline 2. & $\begin{array}{l}\text { Management information system of } \\
\text { human resources work in measurable } \\
\text { goals through training programs. }\end{array}$ & 3.55 & 1.36 & 3.37 & 0.00 \\
\hline 3. & $\begin{array}{l}\text { Management information system of } \\
\text { human resource helps to analyze and } \\
\text { treat goals to reach to the quality of } \\
\text { the training programs. }\end{array}$ & 2.75 & 1.26 & $1.62-$ & 0.11 \\
\hline 4. & $\begin{array}{l}\text { Management information system of } \\
\text { human resources helps in achieving } \\
\text { the requirements of training staff }\end{array}$ & 3.96 & 1.04 & 7.68 & 0.00 \\
\hline 5 . & $\begin{array}{l}\text { Equipment (Hardware) considered } \\
\text { suitable and appropriate for the goals } \\
\text { that have been set and pre-defined } \\
\text { training programs at the corporate } \\
\text { level. }\end{array}$ & 2.93 & 1.14 & $0.53-$ & 0.60 \\
\hline 6. & $\begin{array}{l}\text { Equipment (Software) considered } \\
\text { suitable and appropriate for the goals } \\
\text { that have been set and pre-defined } \\
\text { training programs at the corporate } \\
\text { level. }\end{array}$ & 3.80 & 1.26 & 5.27 & 0.00 \\
\hline & Total & 3.50 & 0.71 & 5.88 & 0.00 \\
\hline
\end{tabular}

\subsubsection{Third Hypothesis}

H3: There is statistically significant relationship between management information systems 
of human resources and implementation of human resources training at the BAU.

Table (5) below shows that all the statements got means greater than 3.00, except the statements No (14). The statement No. 16, which measures the extent to which management information system of human resources increasing the efficiency of the organization through the implementation of training programs, got highest mean 4.09. The statement No. 18, got mean 4.03 in the second rank which measures the availability of equipment, Hardware in training programs which used in the implementation of training. The statement No. 21, got lowest mean 3.43, but it statistically acceptable, which measure the impact of management information system of human resource on the commitment of staff regard to training programs.

The statement No. 14 got 2.75 mean less than 3.00, this shows that management information system of human resource work in the implementation of training programs based on the training methods that are identified.

Overall means was of 3.70 and level of significance is less than 0.05 which indicate that the third hypothesis is accepted, and there is statistically significant relationship between management information systems of human resources and implementation of human resources training at the BAU.

Table 5. Mean, standard deviation, $t$ value and level of significance for the implementation of training programs

\begin{tabular}{|c|l|l|l|l|l|}
\hline No. & Statement & Mean & \multicolumn{1}{|c|}{ Standard } & t-Value & $\begin{array}{l}\text { Level of } \\
\text { Sig }\end{array}$ \\
\hline 7. & $\begin{array}{l}\text { Management information system of } \\
\text { human resource work on organize of } \\
\text { training programs }\end{array}$ & 6.91 & 6.40 & 6.40 & 0.00 \\
\hline 8. & $\begin{array}{l}\text { Management information system of } \\
\text { human resource work in the } \\
\text { implementation of training programs } \\
\text { based on the training methods that are } \\
\text { identified. }\end{array}$ & 2.64 & $2.65-$ & $2.65-$ & 0.01 \\
\hline 9. & $\begin{array}{l}\text { management information system of } \\
\text { human resources increasing the } \\
\text { efficiency of the employees through } \\
\text { the implementation of training } \\
\text { programs }\end{array}$ & 7.86 & 7.18 & 0.00 \\
\hline 10. & $\begin{array}{l}\text { management information system of } \\
\text { human resources increasing the }\end{array}$ & 4.09 & 9.50 & 9.50 & 0.00 \\
\hline
\end{tabular}




\begin{tabular}{|c|c|c|c|c|c|}
\hline & $\begin{array}{l}\text { efficiency of the organization through } \\
\text { the implementation of training } \\
\text { programs }\end{array}$ & & & & \\
\hline 11. & $\begin{array}{l}\text { management information system of } \\
\text { human resources increasing the } \\
\text { productivity of the organization } \\
\text { through the implementation of } \\
\text { training programs }\end{array}$ & 3.84 & 6.10 & 6.10 & 0.00 \\
\hline 12. & $\begin{array}{l}\text { Equipment, Hardware used in training } \\
\text { programs achieves the goals of the } \\
\text { implementation of training }\end{array}$ & 4.03 & 9.10 & 9.10 & 0.00 \\
\hline 13. & $\begin{array}{l}\text { There is written guide for the followed } \\
\text { procedures about how to use the } \\
\text { management information system of } \\
\text { human resources in training programs. }\end{array}$ & 3.86 & 5.67 & 5.67 & 0.00 \\
\hline 14. & $\begin{array}{l}\text { There is no difficulty in dealing with } \\
\text { the management information system } \\
\text { of human resources at the } \\
\text { Implementation of the training } \\
\text { programs. }\end{array}$ & 3.77 & 6.02 & 6.02 & 0.00 \\
\hline 15. & $\begin{array}{l}\text { Management information system of } \\
\text { human resource effects the } \\
\text { commitment of staff regard to training } \\
\text { programs. }\end{array}$ & 3.43 & 3.49 & 3.49 & 0.00 \\
\hline 16. & $\begin{array}{l}\text { There is no objection from some of } \\
\text { the staff to the update that applies to } \\
\text { the training programs }\end{array}$ & 3.77 & 5.95 & 5.95 & 0.00 \\
\hline & Total & 3.70 & 8.93 & 8.93 & 0.00 \\
\hline
\end{tabular}

\subsubsection{Fourth Hypothesis}

H4: There is statistically significant relationship between management information systems of human resources and evaluation and follow up the effectiveness of training at Balqa Applied University. 


\section{MInstitute Macrothink $_{\text {Int }}^{\text {Intis }}$}

Table (6) below shows that all the statements got means grater than 3.00, and the level of significant is less than 0.05 , except the statements No (26), (27), (30). The statement No. 34, which measures the extent to which the use standard tools by management information system of human resources to follow the behavior of workers after the implementation of training programs, got highest mean 3.91. The statement No.33, got mean 3.87 in the second rank which measures how management information system of human resources discover imbalance and difficulties experienced by university. The statement No. 23, got lowest mean 3.52, and it is statistically acceptable, which measure how management information system of human resource provides periodic or special reports covering up the effectiveness of training on an ongoing basis.

The statement No. 26 got 2.61 mean less than 3.00, this shows that management information system of human resource staffs do not receive training on a regular basis to develop their skills.

The statement No. 27 got mean grater than 3.00, and the level of significant is grater than 0.05 this shows staff believe that they can dispense the training programs organized by the management information system of human resources.

The statement No. 30 got mean less than 3.00, this shows that management information system of human resource don't adopt suitable methodology in the appointment of trainees.

Overall means was of 3.51 and level of significance is less than 0.05 which indicate that the fourth hypothesis is accepted, and there is statistically significant relationship between management information systems of human resources and evaluation and follow up the effectiveness of training at Balqa Applied University.

Table 6. Mean, standard deviation, $t$ value and level of significance regard the executive control for assessing and monitoring the effectiveness of the training

\begin{tabular}{|r|l|l|l|l|l|}
\hline No. & Statement Mean & $\begin{array}{l}\text { Standard } \\
\text { Deviation }\end{array}$ & t-Value & $\begin{array}{l}\text { Level of } \\
\text { Sig }\end{array}$ \\
\hline 17. & $\begin{array}{l}\text { Management information system of } \\
\text { human resource provides periodic or } \\
\text { special reports covering up the } \\
\text { effectiveness of training on an } \\
\text { ongoing basis. }\end{array}$ & 1.22 & 3.55 & 0.00 \\
\hline 18. & $\begin{array}{l}\text { Management Information System of } \\
\text { human resource provides standards for } \\
\text { measuring the effectiveness of } \\
\text { training. }\end{array}$ & 1.22 & 4.54 & 0.00 \\
\hline 19. & $\begin{array}{l}\text { Individuals working on the } \\
\text { management information system of } \\
\text { human resources have different } \\
\text { specialization }\end{array}$ & 1.24 & 5.04 & 0.00 \\
\hline
\end{tabular}




\begin{tabular}{|c|c|c|c|c|c|}
\hline 20. & $\begin{array}{l}\text { Management information systems of } \\
\text { human resource staffs receive training } \\
\text { on a regular basis to develop their } \\
\text { skills. }\end{array}$ & 2.61 & 1.19 & $2.73-$ & 0.01 \\
\hline 21. & $\begin{array}{l}\text { Staffs believe that they can dispense } \\
\text { the training programs organized by the } \\
\text { management information system of } \\
\text { human resources. }\end{array}$ & 3.14 & 1.30 & 0.93 & 0.36 \\
\hline 22. & $\begin{array}{l}\text { Training increase of job satisfaction of } \\
\text { the employees at the university. }\end{array}$ & 3.78 & 1.14 & 5.72 & 0.00 \\
\hline 23. & $\begin{array}{l}\text { The management information system } \\
\text { of human resource work adopt } \\
\text { competitive program of vacant posts } \\
\text { for employees. }\end{array}$ & 3.58 & 1.44 & 3.35 & 0.00 \\
\hline 24. & $\begin{array}{l}\text { Management information system of } \\
\text { human resource adopts suitable } \\
\text { methodology in the appointment of } \\
\text { trainees. }\end{array}$ & 2.61 & 1.05 & $3.11-$ & 0.00 \\
\hline 25. & $\begin{array}{l}\text { The used equipment (Hardware) suite } \\
\text { with the needs of the training } \\
\text { programs. }\end{array}$ & 3.81 & 1.00 & 6.71 & 0.00 \\
\hline 26. & $\begin{array}{l}\text { The used equipment (Software) suite } \\
\text { with the needs of the training } \\
\text { programs. }\end{array}$ & 3.84 & 1.07 & 6.55 & 0.00 \\
\hline 27. & $\begin{array}{l}\text { Management information system of } \\
\text { human resources discover imbalance } \\
\text { and difficulties experienced by } \\
\text { university }\end{array}$ & 3.87 & 1.06 & 6.84 & 0.00 \\
\hline 28. & $\begin{array}{l}\text { Management information system of } \\
\text { human resources use standard tools to } \\
\text { follow the behavior of workers after } \\
\text { the implementation of training } \\
\text { programs }\end{array}$ & 3.91 & 1.37 & 5.54 & 0.00 \\
\hline & Total & 3.51 & 0.69 & 3.55 & 0.00 \\
\hline
\end{tabular}

\section{Conclusion}

1) There is statistically significant relationship between management information systems of human resources and identifying training needs in the Al Balqa Applied University.

2) There is statistically significant relationship between management information systems of human resources and setting of training programs goals at Al Balqa Applied University. 


\section{Macrothink}

Business Management and Strategy

ISSN 2157-6068

2013, Vol. 4, No. 1

3) There is a statistically significant relationship between management information systems of human resources and implementation of training programs at Al Balqa Applied University.

4) There is a statistically significant relationship between management information systems of human resources and evaluation and follow up the effectiveness of training programs at Al Balqa Applied University.

5) Management information system of human resources does not help to identify the training needs at the university level in the long term.

6) Management information system human resources does not help to determine individual needs.

7) Management information system of human resources does not help to analyze and treat goals to reach to the quality of the training programs.

8) Equipment (Hardware don't not considered suitable and appropriate for the goals that have been set and pre-defined training programs at the corporate level.

9) Management information system of human resources does not work on the implementation of the training programs based on the training methods that are identified.

10) Staffs who use management information system of human resources do not receive training on a regular basis to develop their skills.

11) Management information system of human resources does not adopt a methodology in the appointment of trainees.

\section{Recommendations}

1) The study recommends that there is need to identify of training needs at the university level in the long term, when designing management information systems of human resources.

2) The study recommends that there is need to take into account identifying the individual needs of the management information system of human resources.

3) The management information system of human resources should help in analyzing and treating goals to reach to the quality of the training programs.

4) The study recommended that Equipment (Hardware should be suitable and appropriate for the goals that have been set and pre-defined training programs at the corporate level.

5) The management information system of human resources should work on Implementation of the training programs based on the training methods that are identified.

6) Employees should be trained to develop their skills in the management information system of human resources should. 
7) The management information system of human resources should adopt methodology in the appointment of trainees.

\section{Acknowledgement}

Mohammed A. Abu Rumman is working as assistant Professor at Department of Business Administration in Al Balqa Applied University, Salt-Jordan. His areas of interest are Human resource, MIS, and Tourism and Hotel Management.

\section{References}

Abdul Razzaq, H. (1993). The extent of the use of accounting information in the administrative decisions related to planning and control job," Unpublished Master thesis, University of Jordan.

Al- Essa, A. (2000). The role of information systems in management decision-making in the Ministry of Education," Unpublished Master thesis, Arab Academy for Banking and Financial Sciences - Amman.

Al-Rawi, H. (1999). Accounting information systems and organization.

Judeh, M. (2008). Research methods in management science. Amman: Zahran Publication House.

Alsebyani, I., \& Juma, I. (1993). Analysis and design accounting information systems. Alexandria: University House.

Debian, \& Abdel-Maksoud, S. (2002). An introduction to accounting information systems. Alexandria: New University House Publishers.

Dhillon, G. (1999). Managing and Controlling computer misuse information management \& computer security, (Vol.7),(4), PP.171-175.

Eldahrawi, K., \& Samir, K. (2000). Accounting information systems. Alexandria: The new University Publication House.

Ghurab, K., \& Hijazi, F. (1999). Management information systems. Alesha'a library.

Glautier, M., \& Underdown B. (1977). Accounting theory and practice. London: Pitman Publishing House.

Hendriksen, E., \& Breda, M. (1992). Accounting theory. ( $5^{\text {th }}$ ed.). Irwin/McGraw-Hill, USA

Kircher P. (1967), Classification \& Coding of Accounting Information, The Accounting Review.

Mubarak, S., \& Rifai, L. (1996). Accounting information systems. $\left(9^{\text {th }}\right.$ ed.), Saudi Accounting Association.

Munir, S, \& Ramadan, G. (1986). Accounting information systems and computer.

Nadari, M. (1990) Information systems and their impact on the effectiveness of the decisions 


\section{Macrothink}

Business Management and Strategy

ISSN 2157-6068

2013, Vol. 4, No. 1

in the Jordanian commercial banks," Unpublished Master thesis, University of Jordan.

Naim, D. (1995). Accounting as a system of information to decision makers. Auditor Journal, (27), Jordan.

Nawaf, K. (1992). Management decisions- taking. Amman Culture Publishing House.

Ramadan, A. (1999). Factors affecting the accounting information systems in the Jordanian industrial public shareholding companies. Unpublished Master thesis, University of Jordan.

Salah al-Din, A. (2001). The economics of accounting and management information systems. Alexandria: New University House Publishers.

To'eima T. (2002). Accounting information systems in the evaluation of investment projects. Cairo-Egypt: Etrak publication house. 